\title{
Cultivation of efficient marine microalgae and their biochemical composition and its antibacterial activity against human pathogens
}

\begin{abstract}
The three marine microalgae (Chlorella vulgaris, Spirulina platensis and Nannochloropsis bacillaris) were collected from Vellar estuary, South east coast of India. These three microalgae were cultivated in respective media and estimated their biochemical composition and antibacterial activity. Simultaneously, these cultures were cultivated in flask containing $500 \mathrm{ml}$ of respective media at lab condition for a period of one month and their growth, $\mathrm{pH}$, biomass and $\mathrm{CO}_{2}$ fixation and carbon content were determined. Based on the growth rate, the $\mathrm{pH}$ of three microalgae in media was observed at lab condition. During maximum growth and biomass, the $\mathrm{pH}$ was found to be ranged between $9 \& 11$ for Spirulina platensis, $7 \& 9$ for Chlorella vulgaris; 8 \& 9 for Nannochloropsis bacillaris. Spirulina platensis and Chlorella vulgaris reached maximum growth rate whereas Chlorella vulgaris and Spirulina platensis showed maximum biomass produced. Chlorella vulgaris and Spirulina platensis attained maximum biomass in media at lab condition, also fixed highest level of carbon dioxide in media but they did not produce maximum biomass, though the growth of Nannochloropsis bacillaris were found high in media at lab condition. Among the three microalgae, Chlorella vulgaris and Spirulina platensis produced highest biochemical compounds. Hence Chlorella vulgaris and Spirulina platensis were selected as efficient microalgae for antibacterial activity against human pathogen. This study revealed that certain green algae and blue green microalgae having high growth, $\mathrm{pH}, \mathrm{CO}_{2}$ fixation, carbon content and biochemical composition paves the way for pharmaceutical activity. Antibacterial activity was evaluated for Chlorella and Spirulina withtheir potential health benefits.
\end{abstract}

Keywords: Chlorella vulgaris, Spirulina platensis, Nannochloropsis bacillaris, $\mathrm{CO}_{2}$ fixation, Biochemical composition, Pharmaceutical activity
Volume 5 Issue 4 - 2017

\author{
P Sampathkumar, R Dineshkumar, $R$ \\ Kumaravel \\ Centre of Advanced Study in Marine Biology, Annamalai \\ University, India
}

Correspondence: P Sampathkumar, Associate Professor, Centre of Advanced Study in Marine Biology, Faculty of Marine Sciences, Annamalai University, India, Tel 91-9486456393, Emailsampathcas@gmail.com

Received: December 08, 2016 | Published: April 07, 2017

\section{Introduction}

Ocean covers nearly $70 \%$ of earth's surface and possesses nearly three lakh described species of plants and animal from marine sources, representing 34-36 phyla and some of them are exclusively of the marine ecosystem. Microalgae are the most important and basic component in marine and fresh water ecosystem. ${ }^{1}$ They are also the primary producers at the base of aquatic food chain and one of the first group be affected by metal pollution and bio indicators of various pollutants. ${ }^{2}$

Algae are known as the most primitive and fast-growing plants in worldwide and they are an important source of useful biomass. Algae do not have morphological features such as roots, stems and nonsterile covering of reproductive cells. ${ }^{3}$ Algae have chlorophyll-'a' as the primary photosynthetic pigment for them to convert light energy into chemical energy by the process of photosynthesis. ${ }^{3}$ According to Brennan et al., ${ }^{4}$ algae have the capability of trapping energy from sunlight ten times higher than the terrestrial plants. However, some of the species are not able to photosynthesize but live in a parasitic form. Algae are found in a wide range of habitats including marine and freshwaters, deserts and even in snow and ice.

There are fresh water and marine microalgae which have high photosynthetic efficiency and possess high cell division rate compared to terrestrial plants. Therefore, they absorb more carbon dioxide by fixation to produce higher biomass at increased growth rates. ${ }^{5,6}$ There are various carbon dioxide sources that may be used for the fixation process which include industrial waste gases, emitted gas from power plants and from the atmosphere. ${ }^{7}$ Some microalgae have higher potential to survive and are capable of fixing carbon dioxide under extreme conditions such as low $\mathrm{pH}$ and acidic gases compared to the terrestrial plants that exhibit fatal effects at these conditions. ${ }^{8}$

Marine microalgae Chlorella vulgaris and Spirulina platensis was capable of producing valuable metabolites, such as proteins, carbohydrates, lipids and vitamins for feed additive, pharmaceutical and nutraceutical purpose. They have diversified use ranging from supply of fatty acids and vitamins for fish in aquaculture systems and the nutritional value of microalgae is influenced by their size, shape, digestibility and biochemical composition. ${ }^{9}$ The production of planktonic organisms in good nutritional condition to feed fish larvae and fingerlings is a basic requirement in a vast majority of farms to add organic and chemical fertilizers into the hatchery ponds. ${ }^{10}$

The biochemical composition in algae can change with altering environmental conditions. In nature, changes in phytoplankton community can modify the food quality and quantity. ${ }^{11}$ The effect of these variations for asset of algae species has been exposed by understanding algal physiology. This pool probably reflects the balance between release and uptake processes, due to the physiological activity of bacteria and phytoplankton biomass and free amino acids in seawater are sometimes not correlated, or may be negatively correlated. ${ }^{12}$ 
To determine the phytochemicals and screen the antimicrobial potential of Desmococcus olivaceus(D. olivaceus) and Chlorella vulgaris (C. vulgaris) against human bacterial pathogens. ${ }^{38}$ The present study was aimed to isolate green microalgae Chlorella vulgaris from the Pichavaram Mangrove Forest, South East coast of India. After being isolated, they were confirmed through morphological structures of microalgae $C$. vulgaris on cultivation of two different medias. Phytochemicals like phenol, tannins, flavonoids, terpenes, terpenoids, alkaloid and saponins were present in the dried biomass and antibacterial activity was showed better results to control infectious human pathogens ${ }^{37}$.However, there are no reports regarding the antibacterial compounds of microalgae against human pathogens except. ${ }^{13}$ The antibacterial study is desirable not only to contribute towards an understanding of ecological interactions but also to assess the potential of algal antimicrobial activity and their possible therapeutic value. The future role of microalgal compounds in drug discovery is especially in the priority areas for development of new medicines, namely to fight viral infections, cancer and combat infections from antibiotic resistant bacteria and fungi. ${ }^{14}$

In view of the above, this study was undertaken with the aim to evaluate three marine micro-algae (Chlorella vulgaris, Spirulina platensis, Nannochloropsis bacillaris) cultivation and biomass harvested from medium (at laboratory condition), analysis of growth factor and also to apply for carbon dioxide sequestration, biochemical composition estimation and anti-bacterial activity of against human pathogen from selected two efficient marine microalgae (Chlorella vulgaris and Spirulina platensis).

\section{Materials and methods}

\section{Sample Collection and Isolation}

The marine algae were isolated from Vellar estuary, Parangipettai, south east coast of India, Tamilnadu. Green algae and Blue-green algae were isolated by serial dilution method which was developed in the microalgae Culture Laboratory, Faculty of Marine Sciences, Annamalai University Parangipettai, India. The species were identified using the morphological characters of green algae Chlorella vulgaris, Nannochloropsis bacillaris and Spirulina platensis. ${ }^{15}$

\section{Stock Culture Maintenance}

All the three strains were grown in $250 \mathrm{ml}$ conical flasks containing $90 \mathrm{ml}$ medium added with $10 \mathrm{ml}(10 \%)$ of inoculum. All the cultures were maintained in an incubator shaker set at $100 \mathrm{rpm}$ at $25^{\circ} \mathrm{C} \pm 1$. The cultures were illuminated with cool fluorescent lamps with the irradiance of $42 \mu$ molm-2s-1 on 12:12 hour light dark- cycle. The stock cultures were maintained by sub culturing into new medium every two months.

\section{Preparation of Inoculum}

The inoculum was prepared from the maintained stock culture for further cultivation. The inoculum was obtained from exponential phase cultures standardized at an optical density of $620 \mathrm{~nm}$.

\section{Optical Density}

The optical density of the culture was determined by taking about $2 \mathrm{ml}$ of the sample from the placed in a cuvette. Then, the optical density of each sample was measured for every two days throughout the growth period ${ }^{16}$ at $620 \mathrm{~nm}$ using Shimadzu UV-Vis Spectrophotometer.

\section{Estimation of $\mathrm{pH}$}

$\mathrm{pH}$ of the media was determined using digital $\mathrm{pH}$ meter.

\section{Determination of Total Biomass}

At the final day of growth, the biomass was harvested by flocculation using alum and it was filtered, allowed to dry under room temperature. The weight of the petriplates was calculated initially to avoid numerical errors. The filtered biomass was kept in sterile dried petriplates were weighed initially and calculated the initial weight (fresh weight or wet biomass). After, it was allowed to dry under (sun) light and the dried biomass in the petriplate was weighted (dry weighted). ${ }^{17}$

The total biomass can be calculated by using the formula as follows, Total biomass $=$ Dry weight - Initial weight (wet biomass)

\section{Preparation of Algal extract}

After freeze-drying, the culturedmicroalgae were grounded into fine powder and each of the materials was homogenized separately. Then, the homogenized microalgae samples were sonicated at $25^{\circ} \mathrm{C}$ for $90 \mathrm{~min}, 3$ times each using $80 \%$ methanol. Crude methanol extracts were concentrated by evaporating the solvent under reduced pressure using rotary evaporator and further subjected to solventsolvent partition chromatography. Prior to the in vitro assays, the solvent extractions from the microalgae were prepared in $100 \mathrm{mg}$ mL-1 concentration, each using Dimethyl Sulfoxide (DMSO).$^{18}$

\section{Estimation of carbon content and carbon dioxide fixation rate}

Dried algal $(0.2 \mathrm{mg})$ samples were placed in $500 \mathrm{ml}$ conical flask and $10 \mathrm{ml}$ of $1 \mathrm{~N}$ potassium dichromate and $20 \mathrm{ml}$ of conc. $\mathrm{H}_{2} \mathrm{SO}_{4}$ mixture was diluted with $200 \mathrm{ml}$ of distilled water and $10 \mathrm{ml}$ of hypophosphate $\left(\mathrm{H}_{3} \mathrm{PO}_{4}\right)$ and $1 \mathrm{ml}$ of diphenyl amine was added. Finally it was titrated against $4 \mathrm{~N}$ ferrous ammonium sulphate (FAS). The end point was brilliant green colour appeared. The carbon content was estimated using the following formula:

\section{$A=3.95 \mathrm{I} / \mathrm{g}(\mathrm{I}-\mathrm{T} / \mathrm{S})$}

where, A is carbon content, $\mathrm{g}$ is weight of the sample, $\mathrm{T}$ is FAS with blank $(\mathrm{ml})$ and $\mathrm{S}$ is FAS with sample $(\mathrm{ml})$. The amount of carbon dioxide fixation rate was estimated using the formula of. ${ }^{19}$

\section{$\mathrm{R} \mathrm{CO}=\mathrm{Cc} \times \mu \mathrm{L}(\mathrm{Mco} 2 / \mathrm{Mc})$}

Where, $\mathrm{R} \mathrm{CO}_{2}$ and $\mu \mathrm{L}$ are the $\mathrm{CO}_{2}$ fixation rate $\left(\mathrm{g} \mathrm{CO}_{2} \mathrm{~m}^{-3} \mathrm{~h}^{-1}\right)$ and the volumetric growth rate ( $\mathrm{g}$ dry weight $\mathrm{m}^{-3} \mathrm{~h}^{-1}$ ) respectively in the linear growth phase. $\mathrm{MCO}_{2}$ and $\mathrm{MC}$ represented the molecular weights of $\mathrm{CO}_{2}$ and elemental carbon respectively, $\mathrm{CC}$ is average carbon content (algal dry weight/g).

\section{Analytical Methods}

The following parameters were determined for all the three microalgae strains: chlorophyll ' $a$ ' content, carotenoid content, biomass and biochemical composition such as protein, carbohydrate and lipid contents and the distribution of fatty acids.

\section{Biochemical composition}

Biochemical composition analysis viz. for protein, dry matter content was done by following standard methods. Protein, ${ }^{20}$ Carbohydrate, ${ }^{21}$ Carotenoid and Chlorophyll ' $\mathrm{a}$ '23 and lipid were analyzed following the methods of. ${ }^{24}$ Triplicate samples were analyzed and the average values were taken. 


\section{Antibacterial Assay}

Antibacterial activity was carried out by using the standard disc diffusion method by Matsunaga. ${ }^{25}$ The test microbial pathogens were obtained from Rajah Muthaiah Medical College, Annamalai University and were Klebsiella pneumoniae, Proteus mirabilis, Vibrio cholerae, Salmonella typhi and Escherichia coli. The crude and fractionated extraction of Chlorella and Spirulina were dissolved in different solvents like Ethanol, Methanol, Chloroform and Diethyl ether. The extracts were applied to $6 \mathrm{~mm}$ dry sterile disc in aliquots of $30 \mu \mathrm{L}$ of solvent, allowed to dry at room temperature and placed on agar plates seeded with microorganisms. The bacteria were maintained on nutrient agar plates and incubated at $37 \mathrm{oC}$ for $24 \mathrm{hrs}$. Zones of growth inhibition were measured after incubation from all the extracts and tested twice at a concentration of $30 \mathrm{mg} \mathrm{disc}^{-1}$

\section{Results and discussion}

\section{The $\mathrm{pH}$ of three micro algae grown in medium at lab condition}

The present investigation is carried out with the parameters viz. $\mathrm{pH}$, growth rate, Biomass and $\mathrm{CO}_{2}$ fixation and carbon content rate of three marine microalgae (Chlorella vulgaris, Nannochloropsis bacillaris and Spirulina platensis)

The $\mathrm{pH}$ was found to be at the range between 8 and 10 in medium inoculated with Chlorella vulgaris, 8 with Nannochloropsis bacillaris and 9-11 with Spirulina platensis.

Optimum $\mathrm{pH}$ for most cultured algal species ranges between 7 and 9, with the optimum $\mathrm{pH}$ being 8.2-8.7. The complete culture collapses due to the disruption of many cellular processes result from failure and maintain an acceptable $\mathrm{pH}$. In the case of high intensity algal culture, the addition of carbon dioxide allows correction for increased $\mathrm{pH}$ which may reaches the limiting values of $\mathrm{pH}$ during Chlorella vulgaris and Nannochloropsis bacillaris growth. ${ }^{26}$

The growth rate of three micro algae in medium at lab condition

The growth rate found to be at range between OD at 1.28 and 2.93 in Chlorella vulgaris, maximum range between OD at 0.606 and 2.19 in Nannochloropsis bacillaris and thehighest growth rate was observed at the OD value of 3.29 during $28^{\text {th }}$ day in Spirulina platensis.

\section{Biomass of three microalgae in medium at lab condition}

The highest biomass was obtained in Spirulina platensis $(0.585 \mathrm{~g} / 500 \mathrm{ml})$ followed by Chlorella vulgaris $(0.4485 \mathrm{~g} / 500 \mathrm{ml})$ and Nannochloropsis bacillarisproduced low biomass $(0.429 \mathrm{~g} / 500 \mathrm{ml})$. The harvesting, thickening and dewatering of microalgae cultures have been extensively reviewed by Kaur $\mathrm{I}^{27}$ Key properties of microalgae which influence their separation are (a) shape [rods, spheres or chains or filaments], (b) size [generally between 2 and $30 \mu \mathrm{m}$ ], (c) specific weight [1.051.1], (d) surface charge [usually negative]. Microalgal cultures to be harvested usually between 0.2 to $2 \mathrm{~g} \mathrm{~L}^{-1}$ solids and for lipid extraction a concentration of at least $20 \mathrm{~g} \mathrm{~L}^{-1}$ solids is required. Filamentous algae such as Spirulina can be harvested by filtration, ${ }^{29}$ but almost all of the algae under consideration as a source of biofuels (e.g., Nannochloropsis or Chlorella) are unicellular and too small for effective filtration. Centrifugation is too energy intensive ${ }^{26}$ and not practical for the extremely high volumes required to be processed for algal biofuels production. Sedimentation is also a possibility, but is generally too slow to be effective. ${ }^{27,28}$

The most commonly considered processes are flocculation followed by floatation or by settling as the first step. Flocculation is the first stage in the bulk harvesting process and is used to aggregate the cells, so increasing their effective particle size and thus easing subsequent centrifugation, filtration or sedimentation steps. ${ }^{29}$ Flocculation can be achieved by the use of inorganic flocculants such as alum ${ }^{27-29}$ or organic flocculants such as chitosan ${ }^{16}$ although the cost of these flocculants is substantial. The flocculant used must be compatible with the need to recycle the water back to the growth system without complex pre-treatment of this recycled water.

\section{Carbon content and $\mathrm{CO}_{2}$ fixation rate by microalgae biomass in medium}

The biomass of Chlorella vulgaris contain maximum carbon content $(22.874 \mathrm{mg} / \mathrm{g})$ followed by Spirulina platensis $(19.367$ $\mathrm{mg} / \mathrm{g})$. Among the three microalgae, Chlorella vulgaris $\left(0.083 \mathrm{gml}^{-}\right.$ $\left.{ }^{1} \mathrm{~d}^{-1}\right)$ and Spirulina platensis $\left(0.070 \mathrm{~g} \mathrm{ml}^{-1} \mathrm{~d}^{-1}\right)$ fixed highest level of $\mathrm{CO}_{2}$ whereas Nannochloropsis bacillaris fixed low level of $\mathrm{CO}_{2}(0.056$ $\left.\mathrm{gml}^{-1} \mathrm{~d}^{-1}\right)$

Highly $\mathrm{CO}_{2}$ tolerant microalgae and cyanobacteria suitable for biological fixation of $\mathrm{CO}_{2}$ are Anacystis, Botryococcus, Chlorella, Rhodobacter, Scenedesmus, Spirulina and Synechococcus. ${ }^{31}$

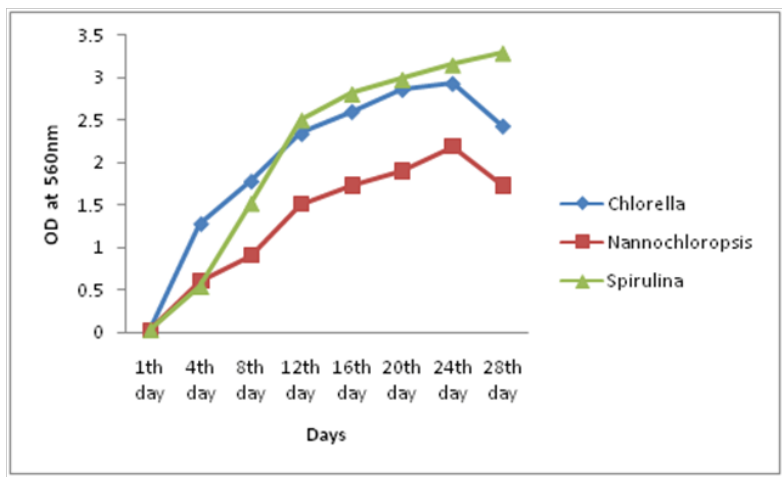

Figure I Growth rate of microalgae in medium at lab condition.

\section{Biomass at laboratory condition (g/500ml)}

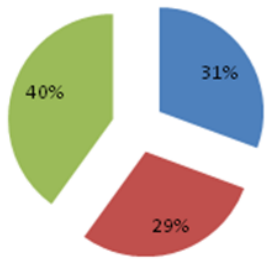

- Chlorella

- Nannochloropsis

In Spirulina

Figure 2 Biomass of three microalgae in medium at lab condition.

\section{Bioactive molecules of pharmaceutical activities of efficient selected microalgae}

The collected three microalgae were found to be grown in media, the maximum growth rate and biomass were obtained only in Chlorella vulgaris and Spirulina platensis not in Nannochloropsis 
bacillaris. Hence, Chlorella vulgaris and Spirulina platensis were selected and its growth and biomass production on the basis of efficiency for bioactive molecules of pharmaceutical activity when compared to Nannochloropsis bacillaris.

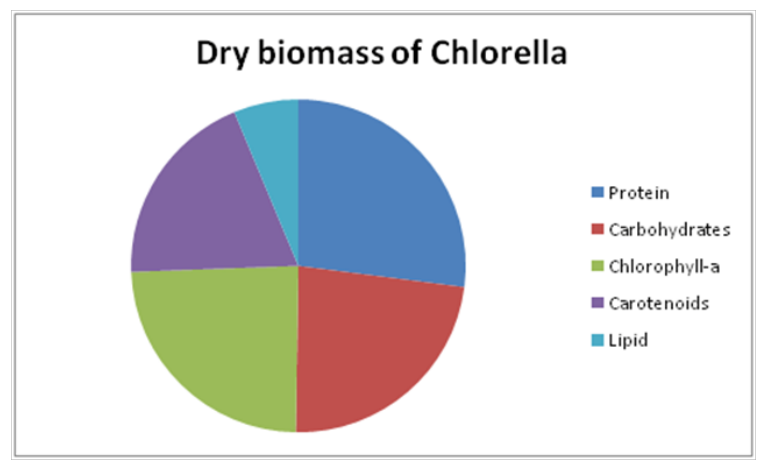

Figure 3 Biochemical composition of Chlorella vulgaris dry biomass.

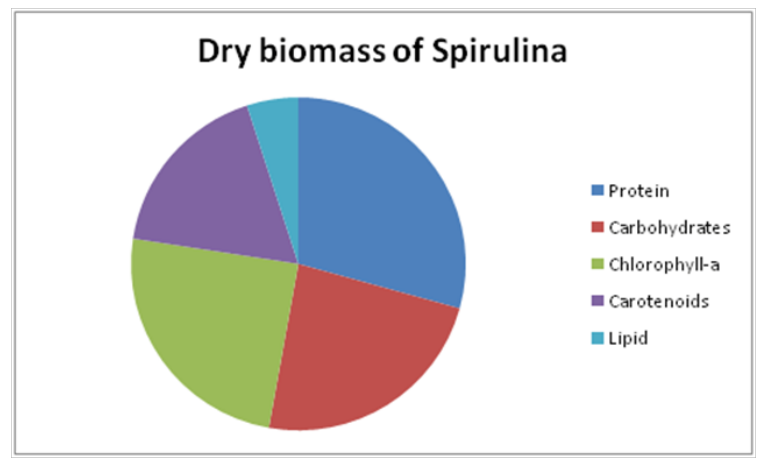

Figure 4 Biochemical composition of Spirulina platensis dry biomass.

\section{Biochemical composition of Chlorella vulgaris dry biomass}

The protein content showed $44.31 \pm 1.33 \mathrm{mg} / \mathrm{g}$ and carbohydrate holds $38.09 \pm 0.92 \mathrm{mg} / \mathrm{g}$. The total chlorophyll 'a' was also analyzed and it was found to be $39.64 \pm 0.81 \mathrm{mg} / \mathrm{g}$. The carotenoids were analyzed and showed $31.63 \pm 0.79 \mathrm{mg} / \mathrm{g}$ dry biomass. The lipid content of Chlorella vulgaris obtained from the dry weight as $10.3 \pm 0.12 \mathrm{mg} / \mathrm{g}$.

\section{Biochemical composition of Spirulina platensis dry biomass}

The protein content showed $48.63 \pm 1.81 \mathrm{mg} / \mathrm{g}$ dry biomass and carbohydrate content showed $39.09 \pm 1.92 \mathrm{mg} / \mathrm{g}$. The total chlorophyll 'a' was also analyzed and it was found to be $40 \pm 1.73 \mathrm{mg} / \mathrm{g}$. The carotenoids were analyzed and it showed $29.18 \pm 0.93 \mathrm{mg} / \mathrm{g}$. The lipid content of Spirulina platensis obtained from the dry weight as $8.3 \pm 0.16 \mathrm{mg} / \mathrm{g}$.

\section{Anti-Bacterial activity assay}

The results obtained from the present study were recorded and analyzed using different solvent against gram negative human pathogens. It is clear from the study that the diameter of the inhibition zone varies with the type of the solvent used and hence varies in antibacterial activity (Table 1\&2).

\section{Anti-bacterial activity of Chlorella vulgaris against human pathogen}

In the present study, Chlorella vulgariswas tested for the antibacterial activity in crude ethanol, methanol, chloroform and diethyl ether. It showed moderate anti-bacterial activity against five pathogens viz. Klebsiella pneumoniae, Proteus mirabilis, Vibrio cholerae, Salmonella typhi and Escherichia coli were assayed (Table 3). Of the test bacteria, Salmonella typhi and Vibrio cholerae was the most sensitive against ethanol and methanol extracts followed by $9.0 \pm 0.7 \mathrm{~mm}$ and $8.5 \pm 0.5 \mathrm{~mm}$ respectively. In test for $C$. vulgaris, gram negative bacteria Salmonella typhi treated with ethanol extract showed the maximum inhibition zone $(13.0 \mathrm{~mm})$, whereas in gram positive bacteria, $C$. botulinum treated with chloroform extract of $C$. vulgaris showed the maximum inhibition zone of $15 \mathrm{~mm} .{ }^{37}$

The antibacterial activity of Chlorella vulgaris extracts were assayed against bacterial strains viz. Bacillus subtilis, Staphylococcus aures, Micrococcus cuteus and Klebsiella pnemoniae by evaluating the inhibition zones and zone diameter values $S$. typhi is a gram negative rod shaped bacteria, a causative agent for enteric fever, sepsis and infectious diarrhea in human beings. The ethanolic extracts of Chlorella showed the antibacterial activity against the human pathogen $S$. typhi and hence it recommends that in adding up to the available drugs, the extracts of Chlorella can be used against the enteric fever, septic and infectious diarrhea or gastro enteritis. It is also suggested that the extracts of $C$. vulgaris may be used to treat urinary tract infections, diarrhea pyogenic infections and septicemia. The ethanol extract of Chlorella showed anti-bacterial activity against $B$. subtilis. Hence, the extract is recommended to treat infections like Bacillus subtilis and S. typhi. Generally Chlorella were found to be effective against only on two pathogen and the anti bacterial activities was found to be dose dependent the phenomenon was in agreement with the findings of. ${ }^{32}$ After being isolated, they were confirmed through morphological structures of microalgae $C$. vulgaris on cultivation of two different Medias. Phytochemicals like phenol, tannins, flavonoids, terpenes, terpenoids, alkaloid and saponins were present in the dried biomass and antibacterial activity was showed better results to control infectious human pathogens. ${ }^{38}$

\section{Anti bacterial activity of human pathogen from various extracts in Spirulina platensis}

In the present study, Spirulina platensis was tested for the antibacterial activity in crude ethanol, methanol, chloroform and diethyl ether. It showed moderate anti-bacterial activity against five pathogens viz. Klebsiella pneumoniae, Proteus mirabilis, Vibrio cholerae, Salmonella typhiand Escherichia coli were assayed (Table 4). Of the test bacteria, Klebsiella pneumoniae and Proteus mirabilis were the most sensitive against ethanol and diethyl ether extracts with $10.0 \pm 0.8 \mathrm{~mm}$ and $7.0 \pm 0.6 \mathrm{~mm}$ respectively followed by Proteus mirabilis and Vibrio cholerae. In chloroform extract, Klebsiella pneumoniae was the most responsive one. The result showed the highest zone of inhibition was observed in Spirulina platensis and the lowest zone of inhibition was observed in Chlorella vulgaris.

Extracts of Spirulina platensis obtained by different solvents exhibited different degrees of antimicrobial activity on gram negative micro organisms. ${ }^{33,34}$ While diethyl ether, ethanol and methanol were the best organic solvents for extracting the antibacterial agents from Spirulina plantensis in the present evaluation. Statistically, the effects of the three diethyl ether, ethanol and methanol were insignificant. Comparatively diethyl ether and ethanol and methanol showed a marked activity against Klebsiella pneumoniae followed by Proteus mirabilis and Salmonella typhi exhibiting $10 \mathrm{~mm}, 8 \mathrm{~mm}$ and $7 \mathrm{~mm}$ of inhibition zone respectively. The same results were also reported by other workers of. . $^{35,36}$ 
The present study indicated that the antibacterial property of the two algal species against the selected strains of human pathogenic bacteria varies depending upon the solvent medium used for extraction. The most sensitive bacteria are Salmonella typhi, P. mirabilis and Klebsiella pneumoniae which were inhibited by ethanol and diethyl ether extracts of $C$. vulgaris. Proteus mirabilis and Salmonella typhi were inhibited by ethanol, methanol and chloroform extracts of $S$. platensis.

Table I pH of three micro algae grown in medium at lab condition

\begin{tabular}{|c|c|c|c|c|c|c|c|c|}
\hline Algae & $I^{\text {th }}$ day & $4^{\text {th }}$ day & $8^{\text {th }}$ day & $12^{\text {th }}$ day & $16^{\text {th }}$ day & $20^{\text {th }}$ day & $24^{\text {th }}$ day & $28^{\text {th }}$ day \\
\hline Chlorella vulgaris & 7.8 & 8.4 & 8.9 & 8.9 & 9.1 & 9.9 & 10.1 & 10.3 \\
\hline Nannochloropsis bacillaris & 7.4 & 7.8 & 8.0 & 8.3 & 8.3 & 8.5 & 8.6 & 8.9 \\
\hline Spirulina platensis & 7.9 & 8.8 & 9.1 & 9.8 & 10.1 & 10.6 & 10.9 & 11.3 \\
\hline
\end{tabular}

Table 2 Carbon content and $\mathrm{CO}_{2}$ fixation by three microalgae biomass

\begin{tabular}{llll}
\hline Parameter & Chlorella vulgaris & Nannochloropsis bacillaris & Spirulina platensis \\
\hline Carbon content $\left(\mathrm{mg} \mathrm{g}^{-1}\right)$ & 22.874 & 15.521 & 19.367 \\
CO2 fixation $\left(\mathrm{g} \mathrm{ml}^{-1} \mathrm{~d}^{-1}\right)$ & 0.083 & 0.056 & 0.070 \\
\hline
\end{tabular}

Table 3 Anti bacterial activity of various extracts in Chlorella against human pathogen

\begin{tabular}{|c|c|c|c|c|c|}
\hline \multirow{2}{*}{ S.No Name of the } & \multirow{2}{*}{ Human Pathogen } & \multicolumn{4}{|c|}{ Concentration/Zone of Inhibition ( $\mathrm{mm}$ ) } \\
\hline & & Ethanol Extract & Methanol Extract & Chloroform Extract & Diethyl Ether Extract \\
\hline $\mathrm{I}$. & Klebsiella pneumoniae & $7.0 \pm 0.5$ & $6.0 \pm 0.3$ & $7.0 \pm 0.4$ & $5.0 \pm 0.5$ \\
\hline 2. & Proteus mirabilis & $5.0 \pm 0.6$ & $6.0 \pm 0.5$ & -- & $8.0 \pm 0.5$ \\
\hline 3. & Vibrio cholerae & & $2.0 \pm 0.7$ & $8.0 \pm 0.5$ & -- \\
\hline 4. & Salmonella typhi & $9.0 \pm 0.7$ & -- & -- & -- \\
\hline 5. & Escherichia coli & $8.0 \pm 0.6$ & $8.5 \pm 0.5$ & -- & $5.0 \pm 0.6$ \\
\hline
\end{tabular}

Table 4 Antibacterial activity of various extracts in Spirulina platensis against human pathogen

\begin{tabular}{llllll}
\hline \multirow{2}{*}{ S.No Name of the Human Pathogen } & \multicolumn{3}{l}{ Counteraction/Zone of Inhibition $\mathbf{( m m )}$} \\
& & Ethanol Extract & Methanol Extract & Chloroform Extract & Diethyl Ether Extract \\
I & Klebsiella pneumoniae & $10.0 \pm 0.8$ & $5.0 \pm 0.5$ & $6.0 \pm 0.3$ & $6.0 \pm 0.5$ \\
2 & Proteus mirabilis & $4.0 \pm 0.9$ & $3.0 \pm 0.2$ & -- & $7.0 \pm 0.6$ \\
3 & Vibrio cholerae & $2.0 \pm 0.3$ & -- & -- & -- \\
4 & Salmonella typhi & $8.0 \pm 0.6$ & -- & $5.0 \pm 0.3$ & -- \\
5 & Escherichia coli & $5.0 \pm 0.4$ & $6.0 \pm 0.3$ & $6.0 \pm 0.3$ & -- \\
\hline
\end{tabular}

\section{Conclusion}

Microalgae are known to be the most biochemical composition and bioactive compound source that has high potential for sequestering carbon dioxide, a greenhouse that leads to global warming. They are extensively exploited for their high lipid production, maximum biomass production and other useful compounds that have great significance in industry and pharmaceuticals. Bio-mitigation of carbon dioxide by the microalgae is one of the promising ways of bioremediation as it can reduce the elevated level of carbon dioxide in the environment.

Microalgae have the potential to change the pharmaceutical industry, providing a solution to transform the existing systems for antibacterial, anti oxidant and anticancer activity and enabling new applications of existing technologies, provided that one can improve its production cost to a point competitive with pharmaceuticals activities.

\section{Acknowledgements}

Authors are thankful to Dean and Director, CAS in Marine Biology, Faculty of Marine Sciences, Parangipettai for providing necessary lab facilities. We are also grateful to the UGC-RGNF; JRF Govt. of India for the financial assistance (Name of the awardee R. Dineshkumar Award letter number and date of UGC Circular number and date F117.1/2015-16/RGNF-2015-17-SC-TAM-24190 \& January 2016).

\section{Conflicts of interest}

None.

\section{References}

1. Li M, Hu C, Zhu Q, et al. Copper and zinc induction of lipid peroxidation and effects on antioxidant enzyme activities in the microalga Pavlova viridis (Prymnesiophyceae). Chemosphere. 2006;62(4):565-572.

2. Sampathkumar P, Kannan L. Seasonal variations in physio-chemical characteristic in the trangueban Nagapattinum region, southeast coast of india. Poll. Res. 1998;17:397-402.

3. John DM, Whitton BA, Brook AJ. The freshwater algal flora of the British Isles an identification guide to freshwater and terrestrial algae. Aquatic conversation. 2003;14(1):105.

4. Brennan L, Owende P. Biofuels from microalgae: A review of technologies for production, processing, and extractions of biofuels and co-products. Renewable and Sustainable Energy Reviews. 2010;14(2):557-577.

5. Kaur I, \& Bhatnagar AK. Algae-dependent bioremediation of hazardous wastes. In: Singh Ved P \& Stapleton Raymond D (Eds.), Progress in Industrial Microbiology. 2002;36:457-516.

6. Mata TM, Martins AA, Caetano NS. Microalgae for biodiesel production and other applications: A review. Renewable and Sustainable Energy Reviews. 2010;14(1):217-232. 
7. Parker M. Commercialization potential of microalgae for biofuels production. Renewable and Sustainable Energy Reviews. 2015;14(9):2596-2610.

8. Sydney EB1, Sturm W, de Carvalho JC, et al. Potential carbon dioxide fixation by industrially important microalgae. Bioresource Technology. 2010;101(15):5892-5896.

9. Kurano N, Ikemoto H, Miyashita H. Fixation and Utilization of Carbon Dioxide by Microalgal Photosynthesis. Energy Conversation Mgmt. 2015;689-692.

10. Brown MR, Dunstan GA, Jeffrey SW, et al. The gross and amino acid compositions of batch and semi-continuous cultures of Isochrysis sp. (CloneT.ISO),Pavlova lutheriandnannochloropsis oculata. J App Phycol. 2014;5(3):285-296.

11. Sa Junior WP. Production of planktonic biomass for feed fingerlings at the Furnas Hydrobiology and Hatchery station. In: Pinto-Coelho RM (Eds.), Ecology and human impact on lakes and reservoirs in Minas Gerais. Belo Horizonte: Segrac. 1994.

12. Butler NM. Lipid storage in diaptomus kenai (Copepod; Calanoida):Effects of inter-and intraespecific variation in food quality. Hydrobiologia. 1994;274(1-3):9-16.

13. Poulet SA, Maartin-JCzBquel V, Delmas D. Gradient of dissolved free amino acids and phytoplankton in a shallow bay. Hydrobiogia. 2011;121(1):11-17.

14. Wasterhoff EG, Dyer WJ. A rapid method of total lipid extraction and purification. Can J Biochem Physio. 2011;137(8):911-917.

15. Khoo M, Coutinho P, Seixas P, et al. Enriching Rotifers with "premium" microalgae Nannochloropsisgaditana. Mar Biotechnol. 2011;11(5):585595.

16. Tomas CR. Identifying Marine Phytoplankton. Academic Press, USA. 1997.

17. Teoh ML, Chu WL, Harvay M, et al. Influence of culture temperature on the growth, biochemical composition and fatty acid profiles of six Antarctic microalgae. Journal of Applied Phycology. 2004;16(6):421430.

18. Stephenson DP, Buchweitz M, Helbig E, et al. Randomized clinical trial of the impact of a nutritional supplement multi mixture on the nutritional status of children enrolled at preschools. Journal de Pediatria. 2010;83:363-369.

19. Khoo M, Coutinho P, Seixas P, et al. Enriching Rotifers with "premium" microalgae Nannochloropsis gaditana. Mar Biotechnol. 2011;11(5):585-595.

20. Yun YS, Lee BS, Park TM, et al. Carbon dioxide fixation by algal cultivation using Waste water nutrients. J Chem Tech Biotechnol. 1997;69:451-455

21. Lowry OH, Rosebrough NJ, Farr A L, et al. Protein measurement with the Folin phenol reagent. J Biol Chem. 1951;193(1):265-275.

22. Dubois M, Gilles KA, Hamilton JK, et al. Calorimetric method for determination of sugars and related substances. Anal Chem. 195628:350-356
23. Strickland JDH, Parsons TR. A Practical Handbook of Seawater Analysis. Bull. Fish. Res. Bd Can. 1968;167:311.

24. Folch JM, Lees GH, Stanely S. A simple method for the isolation and purification of total lipids from animal tissues. J. Biol. Chem. 1957;226(1):497-509.

25. Matsunaga $\mathrm{T}$, Takeyama $\mathrm{H}$, Nakao $\mathrm{T}$, et al. Screening of marine microalgae for bioremediation of cadmium-polluted seawater. $J$ Biotechnol. 1999;70(1-3):33-38.

26. Alma. Antimicrobial and antioxidant property of commonly found microalgae Spirulina platensis, Nostoc muscorum and Chlorella pyrenoidosa against some pathogenic bacteria and fungi. Int J of Pharm Sci Res. 2013;3:4866-4875.

27. Kaur I, Bhatnagar AK. Algae-dependent bioremediation of hazardous wastes. In: Singh Ved P \& Stapleton Raymond D (Eds.), Progress in Industrial Microbiology. 2002;36:457-516.

28. Parker M. Algal capture of carbon dioxide; biomass generation as a too for greenhouse gas mitigation with reference to New Zealand energy strategy and policy. Energy Policy. 2009;37(9):3428-3437.

29. Liu GP, Nadim A, El-Halwagi MM, et al. Design and analysis of biodiesel production from algae grown through carbon sequestration. Clean Technol Environ Policy. 2013;12(3):239-254.

30. Sawayama P, Pinero-Estrada E, del Fresno AMV. Neuroprotection by Spirulina platensis protean extract and phycocyanin against ironinduced toxicity in SH-SY5Y neuroblastoma cells. Toxicol in Vitro. 1995;22(6):1496-1502.

31. Sung KD, Leea JS, Shin CS, et al. CO fixation by Chlorella sp. KR-1 and its cultural characteristics. Bioresource Technology 68. 1999.

32. Mundt SS, Kreitlow A, Nowotny, et al. Biochemical and pharmacological investigations of selected cyanobacteria. Int. J. Hyg. Environ. Health. 1993;203(4):327-334

33. Richmond $\mathrm{B}, \mathrm{Li} \mathrm{Y}, \mathrm{Wu} \mathrm{N}$, et al. $\mathrm{CO}_{2}$ bio-mitigation using microalgae. Appl Microbiol Biotechnol. 2009;79(5):707-718.

34. Otles S, Pire R. Fatty Acid Composition of Chlorella and SpirulinaSpecies. Journal of AOAC International. 2001;84(6):1708-1714.

35. Tzovenui L, Min M, Li Y, et al. Cultivation of Green Algae Chlorella sp. in Different Wastewaters from Municipal Wastewater Treatment Plant. Appl Biochem Biotechnol. 2007;162(4):1174-1186.

36. Tang D, Han W, LI P, $\mathrm{CO}_{2}$ biofixaton and fatty acid composition of Scenedes musobliquus and Chlorella pyrenoidosa in response to different $\mathrm{CO}_{2}$ levels. Bioresource Technology. 2011;102(3):3071-3076.

37. Dineshkumar R, Narendran R, Jayasingam P, et al. Cultivation and Chemical Composition of Microalgae Chlorella vulgaris and its Antibacterial Activity against Human Pathogens. J Aquac Mar Biol. 2017;5(3):00119.

38. Dineshkumar Ramar, Narendran Rajendran, Sampathkumar. Pichai Journal of Coastal Life Medicine. 2016;4(5):374-376. 